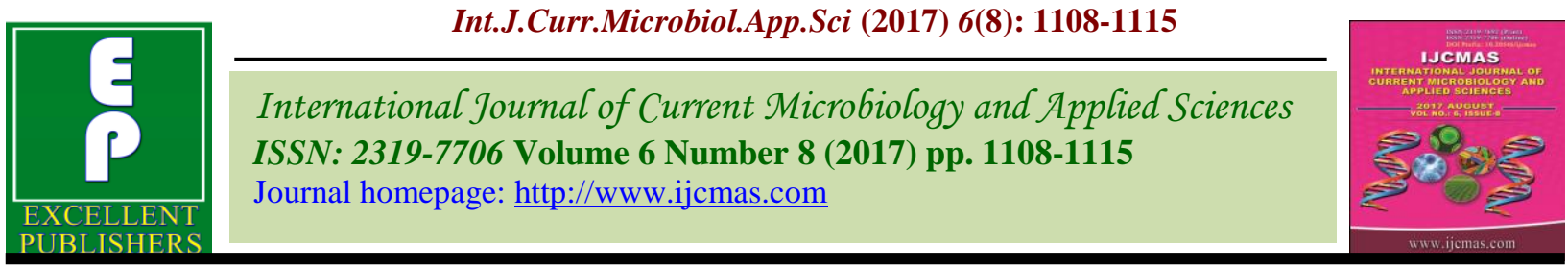

Original Research Article

https://doi.org/10.20546/ijcmas.2017.608.137

\title{
Evaluation of Fungicides, Phyto-extract and Biocontrol Agents against Root Rot of Ajwain in Southern Rajasthan, India
}

\author{
Babu Lal Fagodia*, B.L. Mali and R.K. Fagodiya \\ Department of Plant Pathology, Rajasthan College of Agriculture (MPUAT), \\ Udaipur, Rajasthan 313 001, India \\ *Corresponding author
}

A B S T R A C T

\begin{abstract}
Keywords
Fungicides, Phytoextracts, Bio control agents and Ajwain.

Article Info

Accepted:

14 June 2017

Available Online:

10 August 2017

An investigation was carried out in Rabi season 2015-16 and 2016-17 at Rajasthan College of Agriculture, Udaipur (Rajasthan) to find the role of fungicides, phytoextract and biocontrol agents against root rot of ajwain and results revealed that combined treatments were superior in terms of lower mortality (10.0\%), higher PEDC $(85.71 \%)$, higher grain $(0.52 \mathrm{Kg} / \mathrm{plot})$ yield and higher per cent increase in grain yield $(92.59 \%)$ as compare to the individual treatment. The most effective treatment was seed treatment with Bavistin $(0.1 \%)+$ Neem oil $(0.2 \%)+T$. viride $\left(1 \times 10^{3} \mathrm{cfu} / \mathrm{g}\right)$ followed by Bavistin $0.1 \%+T$. viride $1 \times 10^{3}$ as compared to control as well as other treatments. Studies are therefore, proposed to be undertaken for developing an effective biological control agent using local strain of BCA and its integration with latest fungicides and other control strategies.
\end{abstract}

\section{Introduction}

Ajwain (Trachyspermum ammi L.) known as Bishops weed and Carom seed, is one of the most important seed spice crop it belongs to family Apiaceae is a native of Egypt. Ajwain is erect, glabrous or minutely pubescent branched annual herb which grows up to 75$80 \mathrm{~cm}$ in height. Stem is striate, leaves are distant and 2-3 innately divided segments linear. Flowers are different in colour. The seeds are small yellowish brown in colour. It is a popular seed spice crop in India. The major ajwain producing countries are India, Persia, Iran, Egypt, Afghanistan, Pakistan and North Africa. In India it is widely distributed and its production is concentrated mainly in Rajasthan followed by Gujarat, Madhya Pradesh, Bihar, Utter Pradesh, Punjab, Tamil
Nadu, Andhra Pradesh and West Bengal, respectively. Since ancient time the state of Rajasthan and Gujarat has emerged as "Seed spices bowl". Whose dried fruit of seeds are used as spices.

In Rajasthan, it is cultivated in the districts of Chittorgarh, Udaipur, Jhalawar, Baran, Rajsamand, Bhilwara and Kota covering an area of 11658 hectares with the production and productivity is 4672 tonnes per annum and $401 \mathrm{~kg} / \mathrm{ha}$, respectively (Anonymous, 2015-16). In India, Rajasthan contributes 73 per cent of total production of ajwain. Use of chemical fungicides for effective management of these pathogens is not possible because of the physical heterogeneity of the soil, which 
might prevent effective concentrations of the chemical reaching the target pathogen (Tewari and Mukhopadhyay, 2001). Hence, biological management of root diseases of various field crops including ajwain using microbial antagonists such as Trichoderma spp. have drawn the attention of growers and researchers throughout the world (Padamini, 2014).

\section{Materials and Methods}

Evaluation of fungicides, phytoextracts and biocontrol agents for suppression of root rot of ajwain in field

On the basis of in vitro studies, one promising fungicide, phytoextract and one bio control agent were evaluated alone or in combination against $R$. solani for with each other to observe the suppression of the root rot of ajwain. Local land race of ajwain was used for the study under irrigated condition. Field trials on integrated disease management were conducted during Rabi season of 2015-16 and 2016-17, Department of Plant Pathology, Rajasthan college of Agriculture, Udaipur. Field experiments were laid down in Randomized block design. Plot size $3 \times 3 \mathrm{~m}$ with spacing of $45 \times 25 \mathrm{~cm}$ and replicated thrice. Following treatment were laid out in IDM trial. $\mathrm{T}_{1}-$ Seed treatment with Bavistin $(0.1 \%), \mathrm{T}_{2}-$ Seed treatment with Neem oil $(0.2 \%), \mathrm{T}_{3}-$ Seed treatment with $T$. viride $\left(1 \times 10^{3}\right), \mathrm{T}_{4^{-}}$Seed treatment with Bavistin $(0.1 \%)+$ Neem oil $(0.2 \%), \mathrm{T}_{5^{-}}$Seed treatment with Bavistin $(0.1 \%)+T$. viride $\left(1 \times 10^{3}\right), \mathrm{T}_{6^{-}}$ Seed treatment with Neem oil $(0.2 \%)+T$. viride $\left(1 \times 10^{3}\right), \mathrm{T}_{7^{-}}$Seed treatment with Bavistin $(0.1 \%)+$ Neem oil $(0.2 \%)+T$. viride $\left(1 \times 10^{3}\right), \mathrm{T}_{8^{-}}$Inoculated untreated control and $\mathrm{T}_{9}$ - Un-inoculated untreated control.

Required quantity of fungicide @ $0.1 \%$, (Neem oil)@2.0\% and BCA @ 1 $\times 10^{3}$ alone or in combination of each were used as seed treatment at the time 30 minute before sowing, air dried in shade and then sown. The organic soil amendments (cakes) were added in to the soil two weeks before seed sowing and then soil infested with addition of inoculums@ $25 \mathrm{gm} / \mathrm{sqm}$ at $5-8 \mathrm{~cm}$ depth in the soil. For seed treatment, cultures of the bio-control agents were individually grown on PDA. The sporulating colonies so developed were harvested by suspending in $20 \mathrm{ml}$ water in each Petri plates and mixed with sterilized fine clay (talc powder) $10 \mathrm{~g}$ to make a slurry. The formulation of T. harzianum was used for seed treatments@10 g/ $/ \mathrm{kg}$ seed inoculated in combination of $R$. solani @ 25g/sqm. The coated seeds were kept overnight in moist chamber so as to enable the antagonists to establish on seeds. Observations were recorded on per cent germination, root rot incidence, and grain yield of ajwain seeds in different treatment. The seed germination was recorded at 15 days after sowing and plant mortality was recorded up to 45 days after sowing. Seed yield was recorded for each plot after harvesting.

\section{Results and Discussion}

Evaluation of promising fungicides, biocontrol agents and botanicals for management of root rot of ajwain in-vivo

In the year of 2015-16, the maximum plant mortality $70.0 \%$ was observed in the inoculated untreated control. All the treatments were found to suppress the disease significantly over inoculated untreated control. The lowest plant mortality (10.0\%) and higher PEDC $(85.71 \%)$ was recorded in plots sown to treated finger /sprayed with combinations of Bavistin + Neem oil $+T$. viride as compared to their individual application and rest of other treatments, respectively. While, in other treatments as Bavistin $+T$. viride resulted in significantly lesser per cent mortality and PEDC followed 
by Bavistin + Neem oil and Bavistin alone where plant mortality was recorded 15.8, 20.0 and 24.0 per cent with PEDC was 77.42, 71.42 and 65.71 per cent as compared to control and rest of other. The remaining treatments of Neem oil $+T$. viride and $T$. viride alone resulted in plant mortality as 30.5 and 38.0 per cent with PEDC as 56.42 and 45.71 per cent, respectively. However, plots treated with Neem oil alone had higher plant mortality (43.0\%) and lower PEDC (38.07\%). Whereas, individual application of botanicals was less effective to control the disease and resulted in higher plant mortality and lower PEDC as compared to bio agents and chemicals (Table 1).

In respect to grain yield, minimum yield as $0.27 \mathrm{~kg} /$ plot was recorded in inoculated untreated control plots in the year of 2015-16. All the treatments were found to significantly enhance the grain yield over the inoculated untreated control. The highest grain yield, where $0.52 \mathrm{~kg} /$ plot was recorded in plots treated with Bavistin + Neem oil $+T$. viride, which was also resulted significantly higher per cent increase in grain yield (92.59\%) followed by Bavistin $+T$. viride, Bavistin + Neem oil and Bavistin alone which was resulted the grain yield as $0.49,0.40$ and 0.35 $\mathrm{kg} / \mathrm{plot}$ and increase in grain yield over the inoculated control as 81.48, 48.14 and 29.62 per cent, respectively. The neem oil and $T$. viride individual application which resulted lower finger yields as 0.29 and $0.31 \mathrm{~kg} /$ plot and lesser per cent increase in yield as 7.40 and 14.81 per cent over the inoculated control, respectively (Table 1).

In the year of 2016-17, the maximum plant mortality $71.0 \%$ was observed in the inoculated untreated control. All the treatments were found to suppress the disease significantly over inoculated untreated control. The lowest plant mortality (11.5\%) was recorded in plots treated with combination of Bavistin + Neem oil $+T$. viride which also recorded significantly higher PEDC (83.80\%) followed by Bavistin $+T$. viride and Bavistin + Neem oil resulted in significantly lesser plant mortality with 18.0, 21.0 per cent and higher PEDC was 74.64, 70.42 per cent as compared to its individual applications, respectively. while, the remaining treatments of Bavistin alone, Neem oil $+T$. viride and Neem oil alone was resulted in plant mortality $26.5,34.0$ and 41.0 per cent and PEDC were 62.67, 52.11 and 42.25 recorded. The plots treated with $T$. viride alone which had higher plant mortality 42.0 and lower PEDC 40.84 per cent (Table 2).

In respect to grain yield, minimum yield 0.26 $\mathrm{kg} /$ plot were observed in the inoculated untreated control plot in the year of 2015-16. All the treatments were found to significantly enhance the grain yield over the inoculated untreated control.

The highest grain yield $0.51 \mathrm{~kg} / \mathrm{plot}$ was recorded in plots treated with Bavistin + Neem oilt $T$. viride, which was also resulted significantly higher per cent increase in grain yield $(96.15 \%)$ followed by Bavistin $+T$. viride, Bavistin + Neem oil and which resulted the grain yield as $0.48,0.39 \mathrm{~kg} / \mathrm{plot}$ and increase in grain yield over the inoculated control as 84.61 and 50.00 per cent as compared to their individual applications except to Bavistin, respectively. While, in remaining treatments of Bavistin alone followed by $T$. viride + Neem oil and $T$. viride alone was found superior in grain yield where was $0.34,0.31$ and $0.32 \mathrm{~kg} / \mathrm{plot}$ and per cent increase in grain yield resulted was 30.76, 19.23 and 23.07 per cent. The plots treated with Neem oil resulted lower finger yields as $0.30 \mathrm{~kg} /$ plot and lesser per cent increase of yield as 15.38 over the inoculated control, respectively (Table 2 ). 
Table.1 In-vivo study of efficacy of different promising fungicides, phytoextracts and biocontrol agents on root rot of ajwain during Rabi 2015-16

\begin{tabular}{|c|c|c|c|c|c|}
\hline $\begin{array}{l}\text { S. } \\
\text { No. }\end{array}$ & Treatment & $\begin{array}{c}\text { Plant } \\
\text { mortality* }(\boldsymbol{\%})\end{array}$ & PEDC & $\begin{array}{c}\text { Grain yield** } \\
\text { (Kg/plot) }\end{array}$ & $\begin{array}{c}\text { Per cent increase in } \\
\text { grain yield }\end{array}$ \\
\hline 1 & Bavistin $(0.1 \%)$ & $24.0(29.3)$ & $65.71(54.16)$ & 0.35 & $29.62(28.92)$ \\
\hline 2 & Neem oil $(0.2 \%)$ & $43.0(40.9)$ & $38.57(38.39)$ & 0.29 & $7.40(6.82)$ \\
\hline 3 & T.viride $\left(1 \times 10^{3} \mathrm{cfu} / \mathrm{g}\right)$ & $38.0(38.7)$ & $45.71(42.54)$ & 0.31 & $14.81(14.23)$ \\
\hline 4 & Bavistin + Neem oil & $20.0(26.5)$ & $71.42(57.69)$ & 0.40 & $48.14(47.36)$ \\
\hline 5 & Bavistin + T.viride & $15.8(23.4)$ & $77.42(61.64)$ & 0.49 & $81.48(80.55)$ \\
\hline 6 & Neem oil + T.viride & $30.5(33.5)$ & $56.42(48.69)$ & 0.32 & $18.51(17.89)$ \\
\hline 7 & Bavistin + Neem oil \\
$+T . v i r i d e$ & $10.0(18.4)$ & $85.71(67.79)$ & 0.52 & $92.59(91.55)$ \\
\hline 8 & Inoculated untreated control & $70.0(56.7)$ & - & 0.27 & - \\
\hline 9 & Un-inoculated untreated & $9.50(17.9)$ & - & 0.51 & - \\
\hline & control & & & & 3.326 \\
\hline & SEm \pm & 0.328 & 1.272 & 0.026 & 9.972 \\
\hline
\end{tabular}

*Mean of three replications; Figures in parentheses are arcsine $\sqrt{ }$ per cent angular transformed values and **Average yield 6.33 quintal/ha and Plot size $3 \times 3 \mathrm{~m}$ 
Table.2 In-vivo study of efficacy of different promising fungicides, phytoextracts and biocontrol agents on root rot of ajwain during Rabi 2016-17

\begin{tabular}{|c|c|c|c|c|c|}
\hline $\begin{array}{l}\text { S. } \\
\text { No. }\end{array}$ & Treatment & $\begin{array}{c}\text { Plant } \\
\text { mortality* } \\
(\%)\end{array}$ & PEDC & $\begin{array}{c}\text { Grain } \\
\text { yield** } \\
\text { (Kg/plot) }\end{array}$ & $\begin{array}{l}\text { Per cent } \\
\text { increase in } \\
\text { grain yield }\end{array}$ \\
\hline 1 & Bavistin $(0.1 \%)$ & $26.5(30.9)$ & $\begin{array}{c}62.67 \\
(53.35)\end{array}$ & 0.34 & $\begin{array}{c}30.76 \\
(30.77)\end{array}$ \\
\hline 2 & Neem oil $(0.2 \%)$ & $41.0(39.8)$ & $\begin{array}{l}42.25 \\
(40.54)\end{array}$ & 0.30 & $\begin{array}{c}15.38 \\
(15.39)\end{array}$ \\
\hline 3 & T.viride $\left(1 \times 10^{3} \mathrm{cfu} / \mathrm{g}\right)$ & $42.0(40.3)$ & $\begin{array}{c}40.84 \\
(39.72)\end{array}$ & 0.32 & $\begin{array}{c}23.07 \\
(22.16)\end{array}$ \\
\hline 4 & Bavistin + Neem oil & $21.0(27.2)$ & $\begin{array}{l}70.42 \\
(57.06)\end{array}$ & 0.39 & $\begin{array}{c}50.00 \\
(50.00)\end{array}$ \\
\hline 5 & Bavistin + T.viride & $18.0(25.1)$ & $\begin{array}{c}74.64 \\
(59.77)\end{array}$ & 0.48 & $\begin{array}{c}84.61 \\
(84.16)\end{array}$ \\
\hline 6 & Neem oil + T.viride & $34.0(35.6)$ & $\begin{array}{c}52.11 \\
(46.21)\end{array}$ & 0.31 & $\begin{array}{c}19.23 \\
(19.23)\end{array}$ \\
\hline 7 & $\begin{array}{l}\text { Bavistin }+ \text { Neem oil } \\
+T \text {.viride }\end{array}$ & $11.5(19.8)$ & $\begin{array}{c}83.80 \\
(66.27)\end{array}$ & 0.51 & $\begin{array}{c}96.15 \\
(96.15)\end{array}$ \\
\hline 8 & Inoculated untreated control & $71.0(57.4)$ & - & 0.26 & - \\
\hline 9 & $\begin{array}{l}\text { Un-inoculated untreated } \\
\text { control }\end{array}$ & $9.00(17.4)$ & - & 0.50 & - \\
\hline & $\mathrm{SEm} \pm$ & 0.259 & 0.563 & 0.017 & 6.480 \\
\hline & $\mathrm{CD}$ at $5 \%$ & 0.778 & 1.687 & 0.051 & 19.428 \\
\hline
\end{tabular}

*Mean of three replications; Figures in parentheses are arcsine $\sqrt{ }$ per cent angular transformed values and **Average yield 6.33 quintal/ha and Plot size $3 \times 3 \mathrm{~m}$ 
Table.3 Pooled data of relative efficacy of promising fungicides, phytoextracts and biocontrol agents on root rot of ajwain during Rabi 2015-16 and 2016-17

\begin{tabular}{|c|c|c|c|c|c|}
\hline $\begin{array}{c}\text { S. } \\
\text { No. }\end{array}$ & Treatment & $\begin{array}{c}\text { Plant } \\
\text { mortality* }\end{array}$ & PEDC & $\begin{array}{c}\text { Grain } \\
\text { yield** } \\
\text { (Kg/plot) } \\
\end{array}$ & $\begin{array}{c}\text { Per cent } \\
\text { increase in } \\
\text { grain yield }\end{array}$ \\
\hline 1 & Bavistin $(0.1 \%)$ & $\begin{array}{l}25.25 \\
(30.1)\end{array}$ & $\begin{array}{c}64.19 \\
(53.26)\end{array}$ & 0.34 & $\begin{array}{c}30.19 \\
(29.84)\end{array}$ \\
\hline 2 & Neem oil $(0.2 \%)$ & $\begin{array}{l}42.00 \\
(40.4)\end{array}$ & $\begin{array}{c}40.41 \\
(39.47)\end{array}$ & 0.29 & $\begin{array}{c}11.39 \\
(11.10)\end{array}$ \\
\hline 3 & T. viride $\left(1 \times 10^{3} \mathrm{cfu} / \mathrm{g}\right)$ & $\begin{array}{l}40.00 \\
(39.2) \\
\end{array}$ & $\begin{array}{c}43.27 \\
(41.13)\end{array}$ & 0.32 & $\begin{array}{c}18.94 \\
(18.20)\end{array}$ \\
\hline 4 & Bavistin + Neem oil & $\begin{array}{l}20.50 \\
(26.9)\end{array}$ & $\begin{array}{c}70.92 \\
(57.37)\end{array}$ & 0.40 & $\begin{array}{c}49.07 \\
(48.68)\end{array}$ \\
\hline 5 & Bavistin $+T$. viride & $\begin{array}{l}16.90 \\
(24.2)\end{array}$ & $\begin{array}{c}76.02 \\
(60.71) \\
\end{array}$ & 0.49 & $\begin{array}{c}83.04 \\
(82.36) \\
\end{array}$ \\
\hline 6 & Neem oil $+T$. viride & $\begin{array}{l}32.25 \\
(34.5)\end{array}$ & $\begin{array}{c}54.26 \\
(47.45)\end{array}$ & 0.31 & $\begin{array}{c}18.87 \\
(18.56)\end{array}$ \\
\hline 7 & Bavistin + Neem oil $+T$. viride & $\begin{array}{l}10.75 \\
(19.1)\end{array}$ & $\begin{array}{r}84.75 \\
(67.03) \\
\end{array}$ & 0.51 & $\begin{array}{c}94.37 \\
(93.85)\end{array}$ \\
\hline 8 & Inoculated untreated control & $\begin{array}{l}70.50 \\
(57.1)\end{array}$ & - & 0.27 & - \\
\hline 9 & $\begin{array}{l}\text { Un-inoculated untreated } \\
\text { control }\end{array}$ & $\begin{array}{c}9.25 \\
(17.7)\end{array}$ & - & 0.51 & - \\
\hline & $\mathrm{SEm} \pm$ & 0.232 & 0.305 & 0.008 & 3.154 \\
\hline & CD at $5 \%$ & 0.669 & 0.879 & 0.024 & 9.086 \\
\hline
\end{tabular}

*Mean of three replications; Figures in parentheses are arcsine $\sqrt{ }$ per cent angular transformed values and **Average yield 6.33 quintal/ha and Plot size $3 \times 3 \mathrm{~m}$

The pooled data of year 2015-16 and 201617 , the maximum plant mortality $70.50 \%$ was found in inoculated untreated control plots. All the treatments were found to suppress the disease significantly over inoculated untreated control. The lowest plant mortality $(10.75 \%)$ was recorded in plots treated with combination of Bavistin + Neem oil $+T$. viride, which was found also significantly higher PEDC $(84.75 \%)$ as compared to its individual application and rest of other treatments. While, Bavistin $+T$. viride resulted in significantly lesser plant mortality and higher PEDC followed by Bavistin + Neem oil and Bavistin alone where plant mortality was recorded as 16.90, 20.50 and
25.25 per cent with PEDC as 76.02, 70.92 and 64.19 per cent as inoculated untreated control. The remaining treatments spray with Neem oil $+T$. viride and $T$. viride alone was resulted in plant mortality 32.25 and 40.00 per cent with PEDC 54.26 and 43.27 per cent. The plots treated with Neem oil resulted as higher plant mortality $42.00 \%$ and lower PEDC $40.41 \%$ (Table 3).

In respect to grain yield, minimum yield 0.27 $\mathrm{kg} /$ plot was observed in inoculated untreated control plots in the year 2015-16 and 201617. All the treatments were found to significantly enhance the grain yield over the inoculated untreated control. The highest 
grain yield $0.51 \mathrm{~kg} / \mathrm{plot}$ was recorded in plots treated with Bavistin $+\mathrm{Neem}$ oil $+T$. viride, which also resulted significantly higher per cent increase in grain yield $(94.37 \%)$ as compared to their individual application and rest of treatments. While, Bavistin $+T$. viride was found superior to grain yield and per cent increase in yield followed by Bavistin + Neem oil and Bavistin alone which resulted the grain yield $0.49,0.40$ and $0.34 \mathrm{~kg} / \mathrm{plot}$ and increase in grain yield over the inoculated control was 83.04, 49.07 and 30.19 per cent. The plots treated with Neem oil and $T$. viride resulted lower grain yield as 0.29 and $0.32 \mathrm{~kg} /$ plot and lesser per cent increase of yield as 11.39 and 18.94 per cent over the inoculated control, respectively (Table 3). These BCAs are natural soil inhabitants and once established in the rhizosphere, these are able to suppress the pathogen by active antagonism, mainly antibiosis and competition (Chet, 1989 and Fravel et al., 1985) and also enhance plant growth by production of volatiles (Chang et al., 1986). Of the different methods of application of fungicides and biocontrol agents, seed treatments have been most favoured and used, and there are several studies to show that the BCAs applied on seed established in the rhizosphere and provide good suppression of the pathogens and diseases (De and Mukhopadhyay, 1990; Vyas, 2001 and Xue et al., 2007). The used of BCAs as seed treatment results in their easily establishment in the developing rhizosphere, causing a 'preempt' effect, where the established BCAs are able to suppress the activities of the pathogens through active antagonism (competition, exploitation and antibiosis).

The used of BCAs with fungicides helps in better establishment of plants at initial stages. While the effect of fungicides may be diminished after a certain period, the BCAs continued to grow and multiply in the rhizosphere. The BCAs are also reported to induce resistance in hosts (Kloepper et al., 1993; Van Loon, 1998 and Harman et al., 2004). In several cases, the BCAs have not been found much effective in field. As is clear from the present study, this is because the prevalent pathogens showed variations in sensitivity to BCAs. Similar results have been reported in some earlier work (Dennis and Webster, 1971; Chet, 1989 and Baker and Cook, 1974). Combination of seed treatment with Bavistin + Neem oil $+T$. viride was also effective in suppression of the disease. This treatment may be useful for suppression of soil borne pathogens in organic farming of ajwain as well as for root rot in other crops.

\section{References}

Anonymous. 2015-16. Rajasthan Agriculture Statistics. Directorate of Agriculture, Pant Krishi Bhawan, Jaipur, Rabi Crops, pp. 2-6.

Baker, K.F. and Cook, R.J. 1974. Biological control of Plant pathogens. Freeman, San Fransisco, pp.433.

Chang, Y.C., Baker, R., Kleifield, O. and Chet, I. 1986. Increased growth of plants in presence of biological control agents Trichoderma harzianum. Pl. Dis., 70: 145-148.

Chet, I. 1989. Innovative approaches to plant disease control. John Willey and Sons Inc. New York, USA. pp. 250.

De, R.K. and Mukhopadhyay, A.N. 1990. Control of damping-off in tomato by seed coating with Gliocladium virens. Proc. Int. Conf. Seed Sci. Technol. New Delhi. pp.120.

Dennis and Webster. 1971. Antagonistic properties of species groups of Trichoderma. In Production of nonvolatile antibiotics. Trans. of Brit. Mycol. Soc., 57:25-39.

Fravel, D.R., Marois, J.J., Mumsden, R.D., and Connick, W.J. 1985. Encapsulation of potential biocontrol agents in an 
alginate clay matrix. Phytopathol., 75: 774-777.

Harman, G.E., Howell, C.R., Vitrbo, A., Chet, I. and Lorito, M. 2004 b. Trichoderma species-opportunistic avirulent plant symbionts, Nature Rev. Microbiol., 2: 43-56.

Kloepper, J.W., Tuzun, S., Liu, L. and Wei, G. 1993. Plant growth promoting Rhizobacteria as inducers of systemic disease resistance. In: Lumsden R.D and J.L. Vaugh (eds.) Pest Management Biologically based technologies American Chemical Society, Washington USA. pp. 156-164.

Padamini, 2014. Studies on integrated management of wilt and root rot complex of chickpea (Cicer arietinum L.) caused by Fusarium spp. and Rhizoctonia solani. Ph.D. Thesis, MPUAT, Udaipur (Raj.) pp. 3.
Tewari, A.K. and Mukhopadhyay, A.N. 2001. Testing of different formulation of Gliocladium virens against chickpea wilt-complex. Indian Phytopath., 54: 64-71.

Van Loon, J.C, Baker, P.A.H.M. and Pieterse, C.M.J. 1998. Systemic resistance induced by rhizosphere bacteria. Annu. Rev. Phytopath., 36: 453-483.

Vyas, R.K. 2001. Biological control of Fusarium wilt of cumin (Cuminum cyminum L.). Ph.D. Thesis, MPUAT, Udaipur (Raj.) pp 216.

Xue, A.G., Cober, E., Morrison, M.J., Voldeng, H.D. and Ma, B.L. 2007. Effect of seed treatments on emergence, yield and root-rot severity of soybean under Rhizoctonia solani inoculated field conditions in Ontario. Can. $J . P l$. Sci., 87: 167-173.

\section{How to cite this article:}

Babu Lal Fagodia, B.L. Mali and Fagodiya, R.K. 2017. Evaluation of Fungicides, Phyto-extract and Biocontrol Agents against Root Rot of Ajwain in Southern Rajasthan. Int.J.Curr.Microbiol.App.Sci. 6(8): 1108-1115. doi: https://doi.org/10.20546/ijcmas.2017.608.137 